\title{
ESSAY
}

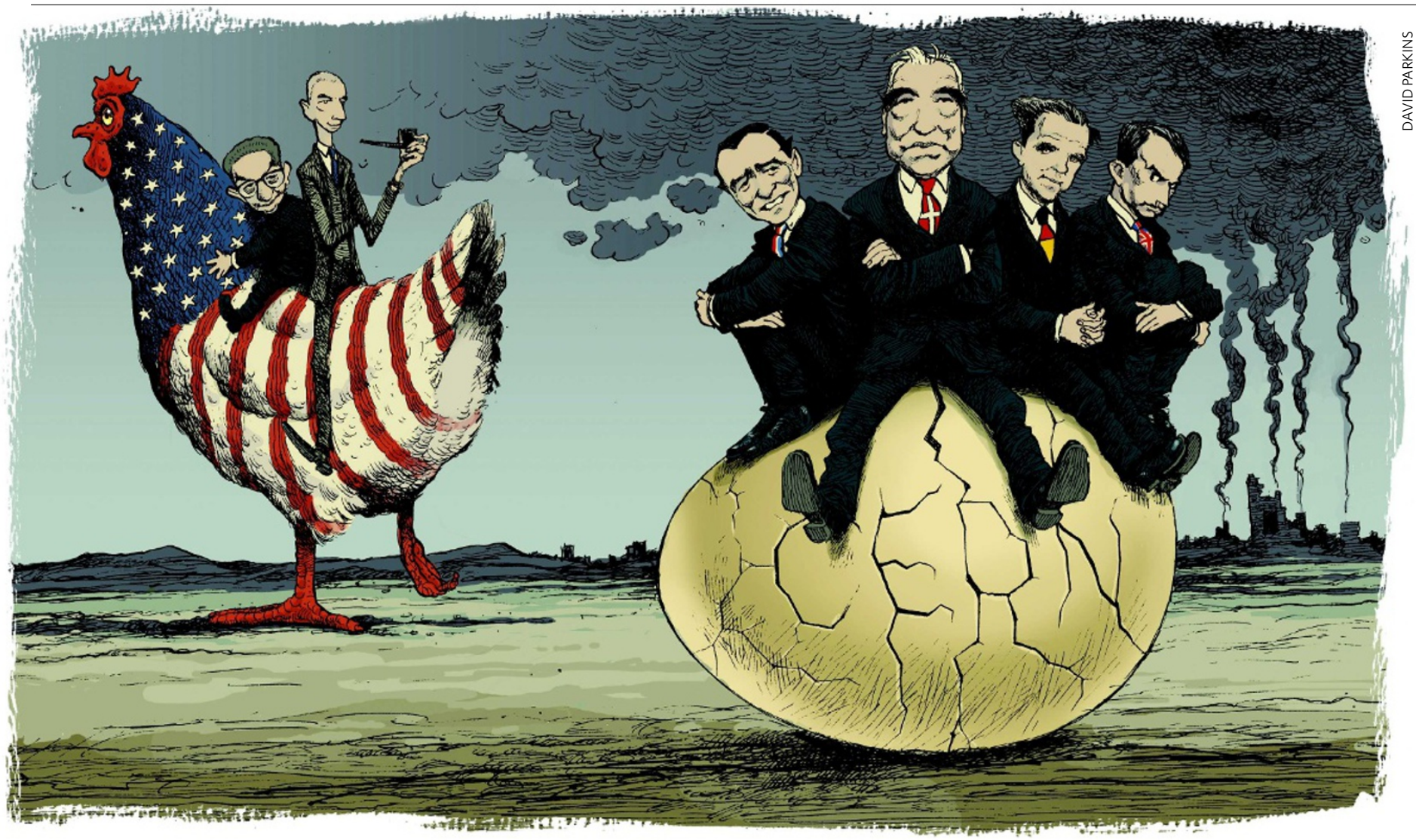

\section{Paris 1951: The birth of CERN}

\section{François de Rose chaired the meeting that founded Europe's premier facility for experimental nuclear and particle research. Here he relives the five days of drama that changed the world of physics.}

As a young French diplomat taking my first steps in international affairs, I had the privilege of representing my country for several years at a United Nations commission in the late 1940s. The United States, under the leadership of the financier and presidential adviser Bernard Baruch and the physicist Robert Oppenheimer, wanted the United Nations to be given oversight of all the world's nuclear weapons and nuclear power - the so-called Baruch plan. The plan failed, but as France was a keen supporter, it gave me the opportunity to work with Oppenheimer. We met frequently to discuss tactics and strategy and soon became friends.

One day, Oppenheimer told me of a problem that was very much on his mind. Most of America's best physicists, he said, had like him been trained, or had worked, in Europe's pre-war laboratories. He believed that Europe's shaken nations did not have the resources to rebuild their basic physics infrastructure. He felt they would no longer be able to remain scientific leaders unless they pooled their money and talent. Oppenheimer also believed that it would be "basically unhealthy" if Europe's physicists had to go to the United States or the Soviet Union to conduct their research.

The solution, Oppenheimer felt, was to find a way to enable Europe's phys-

\section{"It would be basically unhealthy if Europe's physicists had to go to the United States or the Soviet Union to conduct their research."}

European capitals. Slowly the idea that would later become CERN began to take shape.

We had a mixed reception. There was a good deal of support, but some governments and scientists saw the project as too costly at a time when Europe's citizens were being asked to tighten their belts. Others feared it would take money away from individual national labs - which might, in turn, affect the project, because icists to collaborate. When the United Nations commission ended, I returned to France, and raised the idea with our foreign minister Robert Schuman, one of the founders of the European Community. Schuman liked it and allowed me, together with Francis Perrin, then head of France's atomic energy commission, to seek the support of colleagues in other successful international cooperation needed national labs to be well resourced.

Still, by 1950 the project had gained considerable momentum and the American physicist Isidor Rabi had presented the idea to the member states of the United Nations Educational, Scientific and Cultural Organization (UNESCO) at an earlier meeting in 
Florence, Italy. A date was then set for a follow-up meeting at UNESCO headquarters in Paris on 17 December 1951, where the idea would be debated and more details discussed.

\section{View from the chair}

I was asked to chair what would be perhaps the most important meeting in the history of CERN. It was attended by a who's who of twentieth-century physics. G. P. Thomson represented the United Kingdom, Francis Perrin spoke for France, Werner Heisenberg for Gemany and Jakob Nielsen and Niels Bohr represented Denmark. In all, 21 countries sent delegations, as did four international organizations, including the Council of Europe and the then International Council of Scientific Unions (now the International Council for Science). UNESCO was represented by the physicist Pierre Auger.

Delegates had many questions: did Europe really need a new and permanent experimental research facility, or would it be better if scientists collaborated in existing European labs? How much money would such a facility need? Which governments were prepared to pay, and how much would they pledge? Earlier disagreements soon became public as Germany and the United Kingdom, two nations whose support was critically needed, spoke out about their scepticism.

Auger opened by publicly thanking the United States for suggesting the idea to UNESCO. Next, Thomson rose to speak, and as the official report of the meeting records, he got straight to the point: "Britain has, since the war, spent a large sum of money on nuclear physics and especially on large machines. In the present state of financial stringency, further large expenditure by Britain on nuclear physics would not be justified. It must be remembered that there are other expensive branches of science which have a claim on our finances."

Thomson instead favoured the idea that Europe's physicists should collaborate using existing facilities. This would have the advantage that physicists could begin work immediately and not have to wait many years for a new facility to be completed. As a sign of the seriousness of his proposal, Thomson offered the use of a $400-\mathrm{MeV}$ cyclotron at Liverpool University, which was nearing completion.

"The greatness of an institution is not to be measured only, or even mainly, by the size of its budget," he concluded. "Men are more important than machines." Later, Steva Dedijer, the delegate from Yugoslavia, countered: "Europe is supreme in knowing how to develop man. But men can't work without machines. And they will go where there are machines."
For France, Perrin said that the lack of more powerful equipment in the physics of fundamental particles would have the effect of "prejudicing European states and the aspects of civilization that they represent". He reminded the meeting that Europe's scientists would move to America if they couldn't find good facilities at home; and he said that building a machine comparable to those being constructed in the United States would be "far beyond the means of any single European state". Perrin advised that even if the United Kingdom's offer were to be accepted, work on the new laboratory should not be delayed.

The record of the meeting shows that influential backing for Thomson's view came from Heisenberg. "Our country is in an extremely difficult economic position and I am not entitled at the present time to commit our government to any expense in this connection," he said. He too emphasized that it was important that any scheme should produce results quickly and at minimum cost. "One should not just try to copy one of the big American machines." Nielsen, for Denmark, agreed that young researchers from Europe's scientifically less-developed countries were keen to begin work immediately using whatever experimental facilities were available.

Yet, as the meeting progressed, it became clear that more delegates were in favour of building a new machine than against, and concrete offers of support started to come in. By the end, France, Switzerland, Italy, Belgium and Yugoslavia had collectively pledged $\$ 151,000$ towards a feasibility study and Denmark said it would very probably join them. Denmark also proposed Copenhagen as a possible site for the new laboratory, with Belgium and Italy suggesting Geneva.

\section{CERN takes shape}

Two months later, 11 European governments agreed to establish a provisional governing council and the CERN acronym (Conseil Européen pour la Recherche Nucléaire) was born. Thanks to the generosity and farsightedness of Switzerland, Geneva was chosen as the site of the laboratory in October 1952, and in July 1953 the CERN Convention was ratified by the 12 founding member states: Belgium, Denmark, France, the Federal Republic of Germany, Greece, Italy, the Netherlands, Norway, Sweden, Switzerland, the United Kingdom and Yugoslavia.

The first cyclotron - a 600-MeV device came into operation in 1957. Two years later it was joined by the $28-\mathrm{GeV}$ proton synchrotron, which was for a brief period the world's highestenergy particle accelerator.

Today, as CERN enters an exciting new phase, it is worth recalling the many paradoxes in the foundation of this great institution. For example, at the 1951 meeting, unusually for the time, the United Kingdom took an opposite position to America's known wishes. Also unusual was the fact that the United States felt more strongly than Britain the need to strengthen European science, a major component of European culture.

Although early proponents of the idea of CERN also included the influential French physicist Louis de Broglie, it is impossible to overstate how important it was for all the proponents of CERN to have the United States take the lead and present the idea to UNESCO - this made the proposal much harder for others in Europe to oppose. But American support for CERN may have come at a price for American physicists. In later years, US policy-makers have used the existence of CERN as a reason to refuse requests from the US scientific community for expensive highenergy machines in their own country.

Few of us present that December in 1951 thought that by the time the meeting closed there would be so many pledges to take the idea of CERN forward. We began the meeting voicing different points of view, yet holding a unified vision for greater scientific cooperation and lasting peace in our continent. That vision is the one that eventually prevailed. Had the meeting failed, had scientists and governments not been able to agree on a joint programme of action, the repercussions of failure would have been felt far beyond the universe of nuclear physics.

The meeting was a success, and this allowed me to close our deliberations with the remark that: "if it would be difficult to find scientists among diplomats, it was obvious that there were many diplomats among scientists." François de Rose chaired the UNESCO meeting that was held in Paris from 17 to 21 December 1951. He was president of the council of CERN from 1959 to 1962 and was France's ambassador to NATO from 1970 to 1975 . He is the author of La France et la défense de l'Europe (Seuil, 1976), translated as European Security and France (Macmillan, 1984).

\section{See Editorial, page 137.}

This is the first of a series: for more Meetings that Changed the World over the next five weeks see www.nature.com/nature/focus/meetings 